\title{
Phytoplankton dynamics in relation to the biogeochemical cycle of silicon in a coastal ecosystem of western Europe
}

\author{
Olivier Ragueneau ${ }^{1}$, Esther De Blas Varela ${ }^{2}$, Paul Tréguer $^{1}$, Bernard Quéguiner $^{1}$, \\ Yolanda Del Amo ${ }^{1}$
}

\author{
${ }^{1}$ URA CNRS 1513, Institut Universitaire Européen de la Mer, Université de Bretagne Occidentale, BP 452, \\ F-29275 Brest Cedex, France \\ ${ }^{2}$ Universidade de Vigo, Apto. 874, E-36200 Vigo, Spain
}

\begin{abstract}
The Bay of Brest, France, a typical semi-enclosed coastal ecosystem $\left(159 \mathrm{~km}^{2}\right)$ of western Europe, was studied during spring 1992 with respect to the biogeochemical cycle of silicon. Three periods of nutrient and phytoplankton dynamics (chlorophyll a, biogenic silica, species composition), were distinguished during spring 1992, each corresponding, respectively, to a bloom of Thalassiosira sp. and Skeletonema costatum during early spring (April), Rhizosolenia sp. during mid-spring (May) and Chaetoceros sociale during late spring (June). During each period the production of biogenic silica (the mean rate of spring biogenic silica production was $13 \mathrm{mmol} \mathrm{Si} \mathrm{m}^{-2} \mathrm{~d}^{-1}$ ), derived from ${ }^{14} \mathrm{C}$ primary production measurements, size fractionation experiments and appropriate $\mathrm{Si}$ : $\mathrm{C}$ ratios, has been compared with the sum of the silicic acid inputs to the bay originating from rivers, from the adjacent Iroise Sea and from the sediments. From this comparison, it is concluded that (1) the early spring diatom bloom was mainly sustained by silicic acid from the watershed, (2) recycling of silicic acid within the water column played a major role during mid-spring to sustain the bloom of Rhizosolenia sp. and (3) silicic acid recycling at the sediment-water interface was the main contributor to the silica production during the late spring bloom. On a seasonal basis, the riverine inputs of Si (net source) balance the Si burial in sediments (net sink), and the contribution of the sediment to the silica production equals that of the watershed. The factors that govern the quantitative and qualitative variations of phytoplankton blooms during these periods are discussed. In these nitrate-rich coastal waters, support is given to the hypothesis of Si-limitation of the diatom growth, at least during the early spring period when inputs of silicic acid from the watershed represented the major contribution to the silica production.
\end{abstract}

KEY WORDS: Biogeochemical cycle $\cdot$ Coastal ecosystem $\cdot$ Silicon · Phytoplankton dynamics

\section{INTRODUCTION}

The productive period in temperate coastal waters is usually characterized by a typical sequence of events from a spring diatom-dominated bloom, owing to the large amounts of dissolved silicate supplied by rivers through land weathering, to a later summer bloom dominated by non-diatom species, supported by regenerated nutrients (Margalef 1958, Pingree 1978, Peterson 1986). Continuous anthropogenic enrichment of freshwaters by $\mathrm{N}$ and $\mathrm{P}$ compounds, evident for several decades in western Europe (Meybeck \& Helmer 1989, review in Smayda 1990) has led to long-term declines in $\mathrm{Si}: \mathrm{N}$ and $\mathrm{Si}$ : $\mathrm{P}$ ratios. The subsequent possibility of Si-limited diatom blooms in coastal waters which has emerged (Officer \& Ryther 1980, Smayda 1990, Conley \& Malone 1992) altered the typical sequence above, since it provides suitable conditions for a spring flagellate bloom, not only supported by regenerated nutrients, but also by terrigenous new nutrients, leading to most of the well-known coastal eutrophication problems (Billen et al. 1991).

The Bay of Brest, France, is a typical coastal ecosystem of western Europe where such perturbations are likely to occur due to the 10 -fold increase in the nitrate concentrations in its tributaries since the beginning of 
the century (Tréguer \& Quéguiner 1989). Nonetheless, the Bay of Brest has not yet exhibited any symptom of eutrophication (Hily 1991). Given the importance of silicon in the emergence of coastal eutrophication problems (Schelske \& Stoermer 1971), the present study has been performed to assess the biogeochemical cycle of this element in connection with the spring phytoplankton dynamics. Officer \& Ryther (1980) suggested that the shift from a diatom-dominated population to a flagellate-dominated one was mainly controlled by silicic acid regeneration, which usually occurs at the sediment-water interface in coastal waters (Calvert 1983, D'Elia et al. 1983), but which may also occur above the thermocline in stratified systems (Paasche \& Ostergren 1980). The present investigation has thus been undertaken to answer the following questions: What is the relative importance of dinoflagellates as compared to diatoms during the spring bloom? What is the balance between regeneration processes and direct inputs of silicon in this shallow well-mixed coastal ecosystem? Finally, when does the dissolved silicon availability control diatom development, and what precludes the expected subsequent development of dinoflagellates in the Bay?

\section{MATERIAL AND METHODS}

Study site and sampling strategy. The study was conducted in the Bay of Brest (Fig. 1), a productive coastal area fed by 2 small tributaries, the Aulne and Elorn rivers. This bay has already been described as a typical macrotidal semi-enclosed ecosystem (Delmas 1981), connected with the adjacent Iroise Sea through a sound $1.8 \mathrm{~km}$ wide and $50 \mathrm{~m}$ deep.

Water sampling was performed at Stn R3 (Fig. 1), located in Box 6 (Fig. 1) of the Delmas' physical model (Delmas 1981, Delmas \& Tréguer 1985). This box exhibits the following characteristics: (1) it is located at the confluence of the 3 water masses originating from the Elorn River, the Aulne River and the adjacent Iroise Sea and it is therefore considered to be typical of the study area (Quéguiner \& Tréguer 1984, Delmas \& Tréguer 1985, Dauchez et al. 1991); (2) tidal mixing ensures the vertical homogeneity of all nutrient and biomass parameters, including non-conservative properties (Delmas \& Tréguer 1985); (3) all of these para- meters also exhibit little horizontal variability (Hafsaoui 1984); and (4) this box accounts for about $80 \%$ of the whole Bay volume. Primary production data measured at this routine station were used by Quéguiner \& Tréguer (1984) to estimate the annual primary production of the whole Bay of Brest.

Five depths from surface to bottom $(40 \mathrm{~m})$ were sampled once or twice a week, from September 1991 to June 1992, but only the spring period will be discussed here. Samples for determination of ammonium and oxygen were immediately fixed on board the ship, after addition of the working reagents. Samples for determination of other nutrients were preserved either in a refrigerator (silicic acid, $4^{\circ} \mathrm{C}$ ) or in a freezer (nitrate and phosphate, $-20^{\circ} \mathrm{C}$ ) before analysis. Samples for taxonomic determinations were also fixed on board using an acid Lugol solution. The filtrations for particulate matter measurements were carried out at the laboratory $2 \mathrm{~h}$ after sampling. Sediment cores were taken twice a month from March to October 1992, in the sand-silt sediments of Stn F (10 m deep) located 1 nautical mile southeast of Stn R3 (Fig. 1). Freshwater samples were collected once a week at Stn A (Aulne River) and Stn E (Elorn River) (Fig. 1). Daily river flow data were provided by the 'Service Hydrologique Centralisateur' (Nantes, France).

Analytical methods. Temperature was measured using Richter and Wiese reversing thermometers (precision: $\pm 0.01^{\circ} \mathrm{C}$ ). Salinity was measured by the Knudsen method (precision: $\pm 0,03$ PSU). Oxygen was deter- 
mined by the Winkler method, according to Strickland $\&$ Parson (1972) (precision: $\pm 0.04 \mathrm{ml} \mathrm{l}^{-1}$ ). Ammonium measurements were made according to Koroleff (1969) (precision: $\pm 0.05 \mu \mathrm{M}$ ). Phosphate was determined by the method of Murphy \& Riley (1962) (precision: \pm 0.02 $\mu \mathrm{M})$. Nitrate determination was made using a Technicon Autoanalyzer II (Tréguer \& Le Corre 1975) (precision: $\pm 0.1 \mu \mathrm{M})$. Silicic acid (silicate) was determined according to Mullin \& Riley (1965), using an Alpkem RFA-300 analyser (precision: $\pm 0.05 \mu \mathrm{M}$ ). All precisions have been determined using reproductibility experiments (10 replicates).

For determination of biogenic silica (BSi), $500 \mathrm{ml}$ seawater was filtered onto $0.6 \mu \mathrm{m}$ Nuclepore filters. Biogenic silica was determined by using the sodium hydroxide digestion method of Paasche (1973a). This method has been adapted by Brzezinski \& Nelson (1989) to determine both biogenic and lithogenic silica concentrations on the same filter using HF attack after the $\mathrm{NaOH}$ digestion. As demonstrated by Ragueneau \& Tréguer (1994), biogenic silica determination must be corrected, in coastal waters, from lithogenic silica interference. Precision for corrected BSi concentrations is better than $10 \%$ within the period of maximum diatom activity (spring). For particulate organic carbon (POC) and nitrogen (PON) measurements $1 \mathrm{l}$ of seawater was filtered onto Whatman GF/F precombusted $\left(400^{\circ} \mathrm{C}\right)$ filters and further analysis were performed on a modified Carlo Erba analyzer model N 1500 following the method of Strickland \& Parson (1972). Precision for $\mathrm{POC}$ and $\mathrm{PON}$ is $\pm 1 \%$. For determination of chlorophyll a (chl a) and pheopigments, $500 \mathrm{ml}$ of seawater were filtered onto Whatman GF/F filters and the analysis was done by the fluorimetric method of Yentsch \& Menzel (1963), using a calibrated Turner 111 fluorometer (precision: $\pm 0.1 \mu \mathrm{gl}^{-1}$ ). The estimation of cell concentration and taxonomic identification of phytoplankton were made according to Utermöhl (1931). Carbon primary production was measured under natural light conditions from ${ }^{14} \mathrm{C}$ measurements in $250 \mathrm{ml}$ surface water samples (24 h incubation) (Quéguiner \& Tréguer 1984).

Nutrient fluxes at the water-sediment interface were measured in the laboratory according to the core incubation method described by Henriksen et al. (1981), Nedwell (1982) and Souchu (1986). Incubations lasted for $6 \mathrm{~h}$, in darkness and at in situ temperature. Nutrient concentrations in the supernatant water were determined each hour. A reproducibility experiment, performed with 7 different cores, provided a precision of $44 \%$, which is not surprising taking into account the spatial heterogeneity of the sediments. The weight percentage of $\mathrm{BSi}$ in sediments was determined according to the wet alkaline extraction method of DeMaster (1981) (precision of the method: $\pm 5 \%$ ).

\section{RESULTS}

\section{Variations of environmental parameters}

At Stn R3, surface water temperature increased from $9.5^{\circ} \mathrm{C}$ at the end of March 1992 to $16.5^{\circ} \mathrm{C}$ on 16 June 1992 (Fig. 2). Irradiance increased from 1000 to $2500 \mathrm{~J}$ $\mathrm{cm}^{-2} \mathrm{~d}^{-1}$ over this same period (Fig. 2). The springneap tidal cycle is presented in Fig. 2. The mean daily flow of Aulne River decreased from $50 \mathrm{~m}^{3} \mathrm{~s}^{-1}$ in midFebruary to less than $10 \mathrm{~m}^{3} \mathrm{~s}^{-1}$ at the end of the study period, with a temporary increase at the end of April (Fig. 2). From the beginning of April until the end of the study period, irradiance was sufficient $(>1000 \mathrm{~J}$ $\mathrm{cm}^{-2} \mathrm{~d}^{-1}$ ) to sustain photosynthetic activity in surface waters (Quéguiner \& Tréguer 1984).
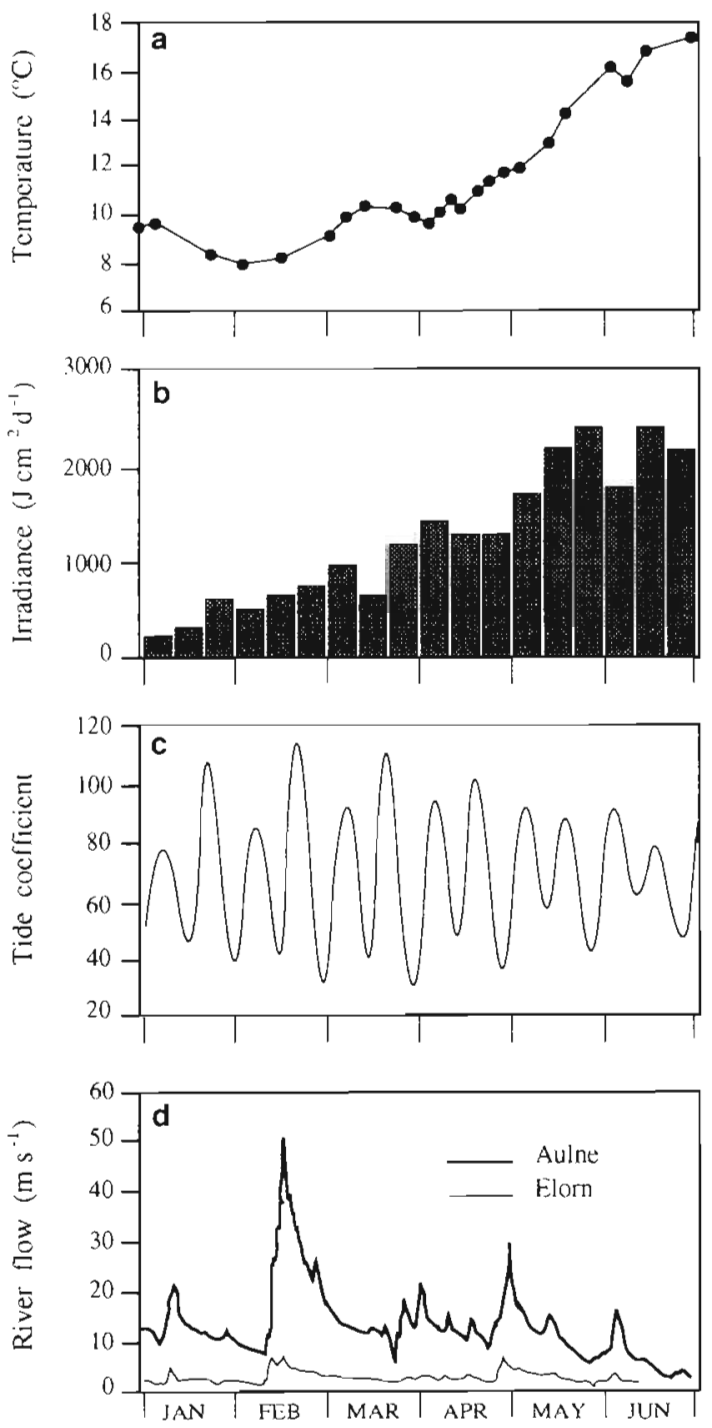

Fig. 2. Temporal variations between January and June 1992 in (a) temperature, (b) irradiance, (c) tide coefficient and (d) daily flows of the 2 major tributaries 

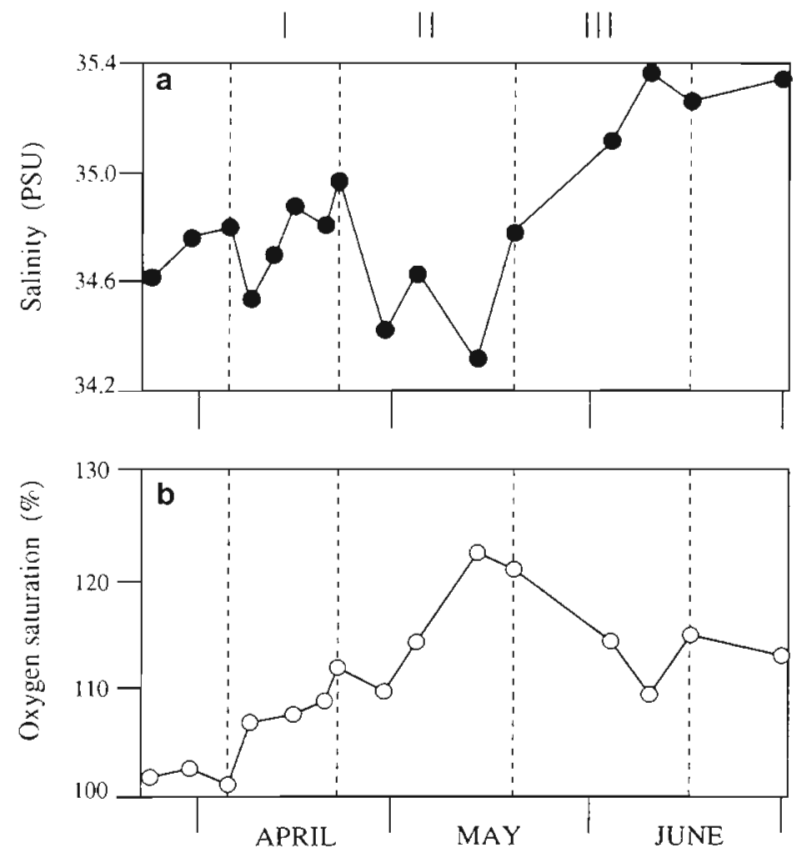

Fig. 3. Temporal variations at Stn $R 3$ between April and June 1992 in (a) salinity concentrations and (b) oxygen saturation. Vertical dashed lines separate the 3 major periods of the study (I: early spring, from 6 April to 23 April; II: mid-spring, from 23 April to 20 May; III: late spring, from 20 May to 16 June)

\section{Variations of chemical and biological parameters in the water column}

Before mid-May, riverine influence was evident in 3 decreases in salinity occuring before 9 April, 30 April and 14 May respectively (Fig. 3). After mid-May, along with the decreasing river discharge, salinity increased up to 35.4 PSU, reflecting the renewal of the waters of the Bay by those of the adjacent Iroise Sea. In relation to the biological activity, oxygen (Fig. 3) was always saturated during the study period, reaching a maximum of $122 \%$ on 14 May coinciding with the second peak of chl a (see below). In parallel to both the increases in oxygen saturation and in biological activity (see below) nutrient stocks exhibited depletion over the whole water column, with a dramatic decrease from 25 March to 13 April (Fig. 4).

As far as nutrients are concerned the following observations can be made. Silicic acid concentrations in surface waters dropped below $1 \mu \mathrm{M}$ on 13 April, i.e. under usual limiting levels of diatom growth in temperate waters (Guillard et al. 1973). Surface concentrations remained below $1 \mu \mathrm{M}$ until the end of June while integrated concentrations in the water column fluctuated between 15 and $40 \mathrm{mmol} \mathrm{m} \mathrm{m}^{-2}$. Phosphate decrease was parallel to that of silicic acid: surface phosphate concentration was $<0.2 \mu \mathrm{M}$ on 13 April and
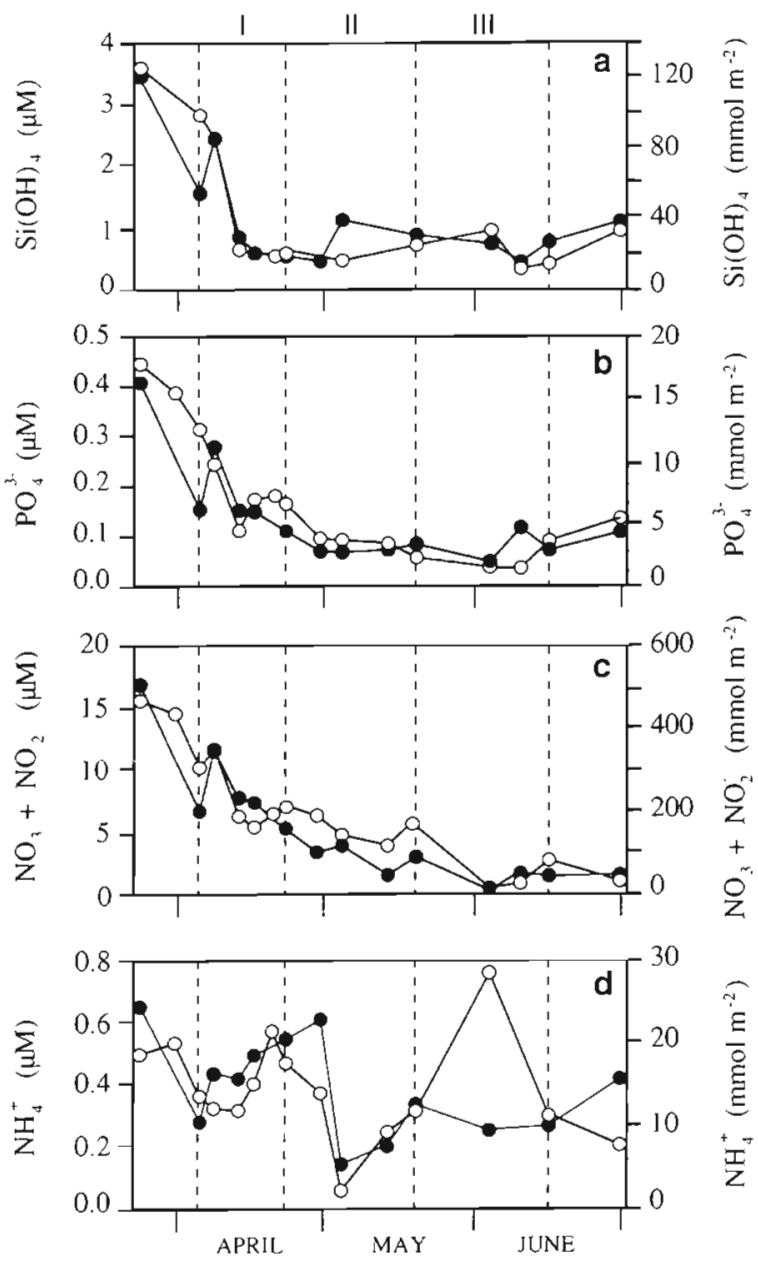

Fig. 4. Temporal variations at Stn R3 between April and June 1992 in (O) surface and (e) depth-integrated concentrations of (a) silicic acid, (b) phosphate, (c) nitrate + nitrite and (d) ammonium

remained below $0.1 \mu \mathrm{M}$ during May; integrated phosphate concentration remained below $5 \mathrm{mmol} \mathrm{m}^{-2}$ until the end of June. Surface nitrate concentrations decreased to $5 \mu \mathrm{M}$ on 13 April and remained just below this level until the end of May. Nitrate exhaustion finally occurred only at the beginning of June and the concentration was $<2 \mu \mathrm{M}$ until the end of the study period. Integrated nitrate concentrations also exhibited a regular decrease until 4 June when surface and integrated values approached zero. Ammonium exhibited a different behaviour as compared to the 3 other nutrients: in surface waters 2 maxima were observed on 21 April and 4 June, whereas integrated values exhibited 3 maxima on 30 April, 20 May and 1 July respectively. Those variations in ammonium concentrations can be related to the intensification of the microzooplankton recycling activity following phytoplankton developments in coastal temperate waters (Ambler et al. 1985). 

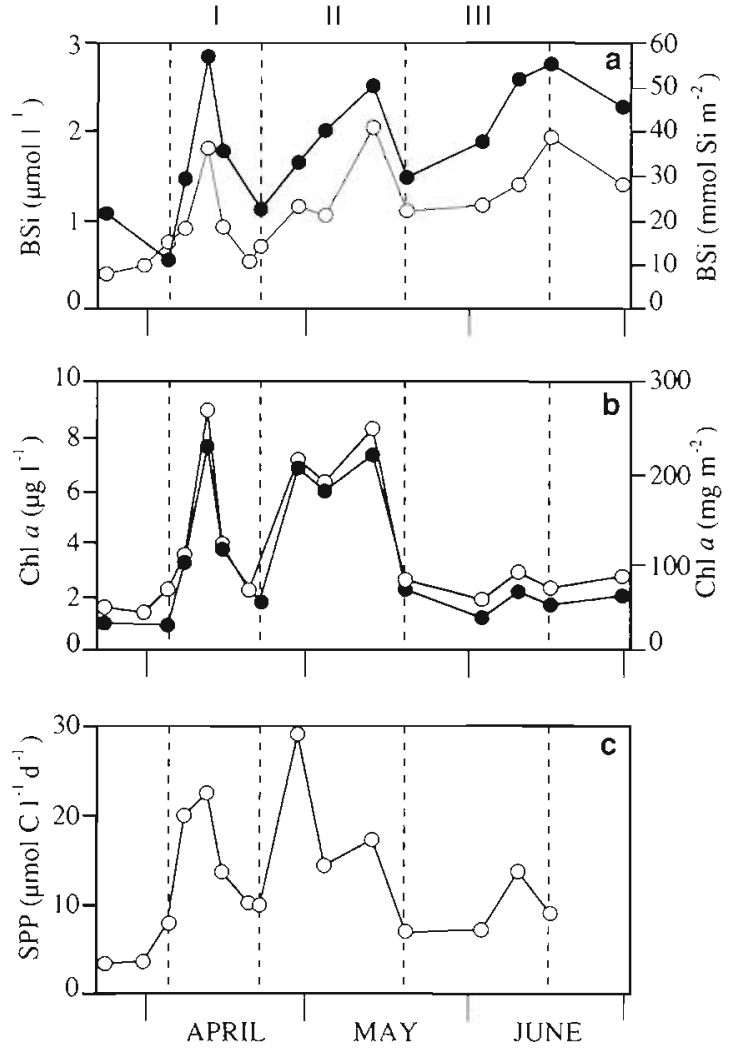

Fig. 5. Temporal variations at Stn R3 between April and June 1992 in (O) surface and (O) depth-integrated concentrations of (a) biogenic silica, (b) chlorophyll $a$ and (c) surface primary production

With respect to the variability of phytoplankton and nutrient dynamics during spring 1992, we can distinguish 3 major periods (I, II and III on figures) each including at least a peak of biomass and production (Figs. 5 \& 6). Period I refers to early spring, from 6 to 23 April, and is centered on the first phytoplankton bloom (13 April); period II refers to mid-spring, from 23 April to 20 May and contains an extended peak with 2 secondary peaks of biomass and production (30 April and 14 May); period III refers to the late spring period, from 20 May to 6 June, including a smaller peak both for biomass and production.

Period I. The first spring bloom was characterized by a rapid and simultaneous growth of both diatoms (dominated by Thalassiosira sp. and Skeletonema costatum) and dinoflagellates, belonging mainly to the nanophytoplankton size class (Fig. 7). The maximum phytoplankton concentration was reached on 13 April, at the end of a neap tide period. The carbon primary


those of chl a (9 $\left.\mathrm{\mu g} \mathrm{l}^{-1}\right)$ and BSi (1.8 $\left.\mu \mathrm{mol} \mathrm{l}^{-1}\right)$ (Fig. 5), together with a severe decrease in nutrient concentrations (Fig. 4). During this early spring period, the


Fig. 6. Temporal variations at Stn R3 between April and June 1992 in (O) surface and (O) depth-integrated concentrations of (a) pheophytin, Pheo., (b) particulate organic carbon, POC, and (c) particulate organic nitrogen, PON
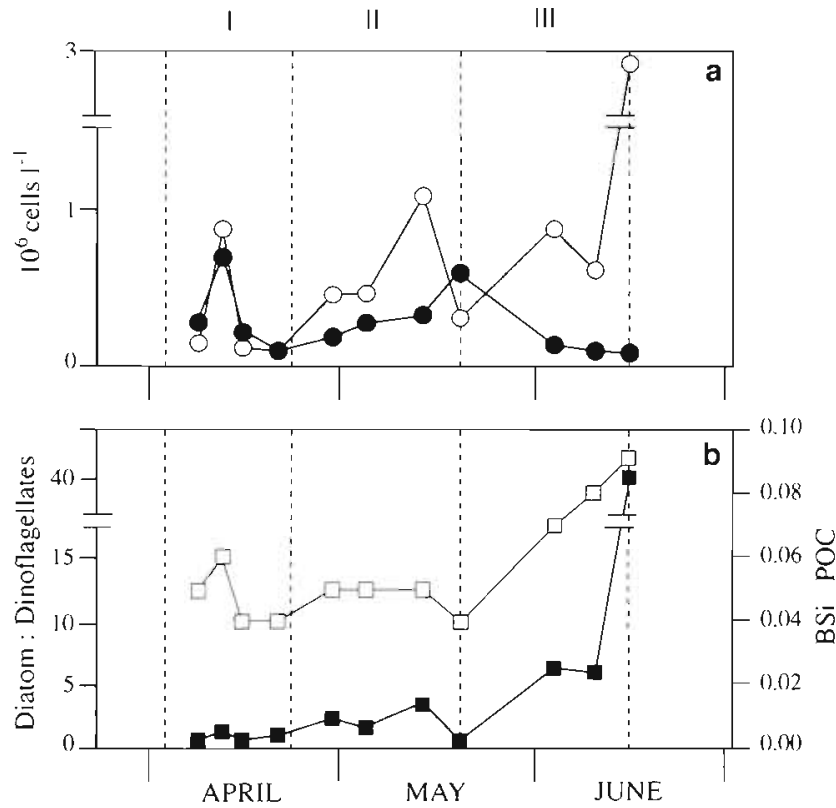

Fig. 7. (a) Temporal variations at Stn R3 between April and June 1992 in (O) diatom and (O) dinoflagellate numerical abundance. (b) Similarities in the variations, during the same period, in ( $\boldsymbol{\square})$ the numerical abundance diatom: dinoflagellate ratio and $(\square)$ in the molar $\mathrm{BSi}$ : $\mathrm{POC}$ ratio 
diatom:dinoflagellate numerical abundance ratio stood between 0.7 and 1.3 (Fig. 7). BSi:POC molar ratios were about 0.05 (Fig. 7), i.e. much lower than the average ratio of 0.13 given by Brzezinski (1985) for diatoms growing in nutrient replete conditions. This reflects the fact that the phytoplankton community was not strongly dominated by diatoms (Fig. 7). On 16 April, the end of the bloom was marked by a strong decrease in every phytoplankton standing stock parameter.

Period II. The second phytoplankton bloom (between 30 April and 14 May) was dominated by diatoms (Fig. 7), mainly Rhizosolenia sp., Thalassiosira sp. and Chaetoceros sp. On 14 May the diatom:dinoflagellate ratio reached a value as high as 3.5 (Fig. 7) which was concommitent with high concentrations of BSi $(2 \mu \mathrm{mol}$ $\left.\mathrm{l}^{-1}\right)$, chl a $\left(8.1 \mathrm{\mu g} \mathrm{l}^{-1}\right)$ and POC $\left(37 \mu \mathrm{mol} \mathrm{l}^{-1}\right)$ (Figs. 5 \& $6)$. The fact that BSi:POC molar ratios remained nearly constant as compared to the previous bloom, in spite of the increasing proportion of diatoms (Fig. 7), could be explained by an increasing proportion of detrital carbon in the particulate matter. This is consistent with pheophytin variations: on 5 May, depth integrated pheopigments exhibited a marked peak $\left(70 \mathrm{mg} \mathrm{m}^{-2}\right)$, indicating an enhanced phytoplankton degradation over the whole water column - an observation consistent with the expected enhanced zooplankton concentration at mid-spring (Quéguiner 1982). Carbon primary production was maximum on $30 \mathrm{April}(29 \mathrm{\mu mol} \mathrm{C}$ $\mathrm{l}^{-1} \mathrm{~d}^{-1}$, i.e. at the beginning of that bloom, and chl $a$ concentrations remained at high levels between 30 April and mid-May (Fig. 5).

Period III. During the late spring period, a moderate bloom of Chaetoceros sociale, accounting for $99 \%$ of diatoms and $83 \%$ of total cell concentration, developed between 10 and 16 June (Fig. 7). Cells belonged to the nanophytoplankton and formed chains as usually observed for this species (Alldredge \& Gotschalk 1989). Low chl a values (maximum of $2 \mu \mathrm{g} \mathrm{l}^{-1}$ for $3 \times$ $10^{6}$ cells $1^{-1}$; Figs. $5 \& 7$ ) corresponded to this bloom. Identical conditions have already been noticed during spring 1981 by Quéguiner (1982) who observed a bloom of $C$. sociale characterized by high cell concentrations (up to $12 \times 10^{6}$ cells $1^{-1}$ ), comparatively moderate chl a values (not exceeding $7.5 \mu^{-1} \mathrm{l}^{-1}$ ), and moderate carbon production rates (maximum:

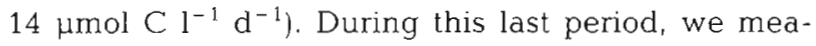
sured a BSi maximum close to $2 \mu \mathrm{mol} \mathrm{Si}{ }^{-1}$ although the diatom:dinoflagellate ratio reached 40 , the maximum value ever observed during the whole study period (Fig. 7). Due to the development of this monospecific bloom of $C$. sociale, the BSi:POC ratio increased to 0.09 (Fig. 7). This value is close to the average Si:C ratio given by Bzrezinski (1985) for siliceous nanophytoplankton.

\section{Silicic acid benthic fluxes and BSi storage in sediments}

Unlike nitrate and ammonium whose fluxes at the water-sediment interface did not appear very active before summer (Souchu 1986), benthic silicic acid fluxes (Table 1) showed a strong increase from 31.5 $\mu \mathrm{mol} \mathrm{m} \mathrm{m}^{-2} \mathrm{~h}^{-1}$ in March to $107 \mu \mathrm{mol} \mathrm{m}^{-2} \mathrm{~h}^{-1}$ in June. These fluxes were highly correlated to bottom water temperature $(\mathrm{r}=0.97 ; \mathrm{n}=8 ; \alpha<0.001)$, a result consistent with those from Rippey (1983) and Boynton et al. (1989). Our measurements of silicic acid fluxes are higher than the diffusive fluxes ( 30 to $50 \mu \mathrm{mol} \mathrm{m}^{-2} \mathrm{~h}^{-1}$ ) calculated by Douchement (1987) from gradients of silicic acid concentrations in pore waters measured at the same station during spring 1985. This is a common observation also reported, for instance, by Quigley \& Robbins (1984) and by Conley et al. (1988), who explained the difference between the 2 fluxes by the major importance of the surface floc layer in BSi dissolution processes.

The weight percentage of BSi content in the sediment showed a 3-fold increase between March and the begining of our study period. This is related to the sedimentation of siliceous material following diatom blooms in the water column during spring (Bienfang et al. 1982). It is worthwhile to note that after this increase, the silica content of the sediment remained around $1 \%$ during the overall study period. Such a low BSi content of the sediment has already been encountered in various locations such as Chesapeake Bay, USA, (D'Elia et al. 1983) or the nondepositional areas of Lake Michigan, USA (Conley et al. 1988). They are low as compared to other coastal deposits which may contain as much as $4 \%$ of BSi in Long Island Sound, USA (DeMaster 1981), 19\% in Saanich Inlet, British Columbia, Canada (Gucluer \& Gross 1964), and even more than $50 \%$ in the central Gulf of California, Mexico (Calvert 1966). This suggests either a low BSi deposition (with a production exported out of the Bay or

Table 1. Temporal variations at Stn F between March and June 1992 in bottom water temperature (T), weight percent biogenic silica (BSi) content of the sediment and silicic acid benthic fluxes $\left[\mathrm{Si}(\mathrm{OH})_{4}\right.$ flux $]$. nd: not determined

\begin{tabular}{|lccc|}
\hline Date & $\begin{array}{c}\mathrm{T} \\
\left({ }^{\circ} \mathrm{C}\right)\end{array}$ & $\begin{array}{c}\text { Weight \% BSi } \\
(\%)\end{array}$ & $\begin{array}{c}\text { SilOH })_{4} \text { flux } \\
\left(\mu \mathrm{mol} \mathrm{Si} \mathrm{m}{ }^{-2} \mathrm{~h}^{-1}\right)\end{array}$ \\
\hline $05 \mathrm{Mar}$ & 9.0 & $0.36 \pm 0.02$ & nd \\
06 Apr & 9.7 & $0.99 \pm 0.05$ & $31.5 \pm 13.9$ \\
$30 \mathrm{Apr}$ & 11.6 & $0.95 \pm 0.05$ & $36.0 \pm 15.8$ \\
14 May & 11.8 & $0.81 \pm 0.04$ & $63.3 \pm 27.9$ \\
04 Jun & 17.8 & $1.22 \pm 0.06$ & $87.4 \pm 38.5$ \\
16 Jun & 16.9 & $0.82 \pm 0.04$ & $107.1 \pm 47.1$ \\
\hline
\end{tabular}


rapidly recycled within the water column) or a rapid $\mathrm{BSi}$ dissolution within the sediment, with a greater importance of BSi dissolution from recent siliceous deposition on surficial sediment rather than BSi dissolution within the sediment matrix (Yamada \& D'Elia 1984).

\section{DISCUSSION}

For each of the 3 periods described above we compared the biogenic silica production in the whole Bay of Brest with the sum of silicic acid inputs originating from various sources. The subsequent fate of the biogenic silica produced was also examined.

\section{Estimates of biogenic silica production}

A first order approximation of the biogenic silica production in the Bay of Brest has been determined from conversion of the integrated carbon primary production using appropriate $\mathrm{BSi}: \mathrm{POC}$ ratios (Brzezinski 1985). Different steps were required for the calculation.

Step 1. Calculation of the depth-integrated primary production. Although we only measured surface carbon primary production during spring 1992 (Fig. 5), a reasonable estimate of depth-integrated carbon primary production (IPP) can be calculated by taking into account the linear regressions between IPP and SPP (Table 2). Those regressions were established by using a previous data set (120 data for spring 1981, 1982 and 1983) obtained for the same station and the same season by Quéguiner \& Tréguer (1984) and Hafsaoui et al. (1985). We divided the water column into 4 horizontal sections whose corresponding area was known (Berthois \& Auffret 1970); for each section, we established the regression between depth-integrated production and surface primary production (Table 2). Estimates of IPP (mmol C m $\mathrm{m}^{-2} \mathrm{~d}^{-1}$ ) were made by using these regressions. For example, SPP measured on

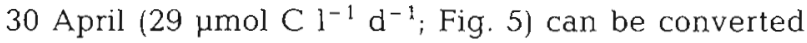

Table 2. Relationship between integrated carbon primary production (IPP, mmol $\mathrm{C} \mathrm{m}^{-2} \mathrm{~d}^{-1}$ ) for different depth intervals and surface carbon primary production (SPP, mmol $\mathrm{C} \mathrm{m}^{-3}$ $\mathrm{d}^{-1}$ ). ${ }^{14} \mathrm{C}$ data from Stn R3 collected during springs 1981, 1982 and 1983 (total 120 data points)

\begin{tabular}{|ccc|}
\hline $\begin{array}{c}\text { Depth } \\
(\mathrm{m})\end{array}$ & Linear regression & $\begin{array}{c}\mathrm{r} \\
(\mathrm{n}=30)\end{array}$ \\
\hline $0-5$ & $\mathrm{IPP}=[4.2( \pm 0.3) \times \mathrm{SPP}]+3.9( \pm 5.9)$ & 0.94 \\
$5-10$ & $\mathrm{IPP}=[3.1( \pm 0.4) \times \mathrm{SPP}]+3.7( \pm 8.1)$ & 0.85 \\
$10-20$ & $\mathrm{IPP}=[3.8( \pm 0.6) \times \mathrm{SPP}]-3.8( \pm 13.4)$ & 0.76 \\
$20-40$ & $\mathrm{IPP}=[0.9( \pm 0.2) \times \mathrm{SPP}]-2.6( \pm 5.3)$ & 0.56 \\
\hline
\end{tabular}

into an IPP of $125.7 \pm 5.9 \mathrm{mmol} \mathrm{C} \mathrm{m}^{-2} \mathrm{~d}^{-1}$ for the 0 to $5 \mathrm{~m}$ depth layer. This approach provides a useful tool to predict depth-integrated carbon primary production from surface measurements only, and has been validated during spring 1993. During the 1993 phytoplankton spring bloom, primary production was measured at 5 depths at the same station; between 19 April and 30 June 1993, IPP was $77 \pm 8 \mathrm{~g} \mathrm{C} \mathrm{m}^{-2}$. Conversion of SPP into IPP during this bloom period using Table 2 provides an estimated value of $92 \pm 27 \mathrm{~g} \mathrm{C} \mathrm{m}^{-2}$, in reasonable agreement with the measured value.

Step 2. Contribution of diatoms to carbon primary production. Since only diatoms contribute to the silica production in the Bay (other siliceous contributors are of negligeable importance), it is necessary to estimate the proportion of the carbon primary production which was due to only diatoms. Diatoms always accounted for at least $87 \%$ of the microphytoplankton (assuming cells with a diameter $>10 \mu \mathrm{m}$ belong to microphytoplankton) during spring 1992 in the Bay. According to size-fractionation experiments carried in 1993 (H. Breton, B. Quéguiner, Y. Del Amo \& P. Tréguer unpubl.) in the Bay of Brest $(0.2$ to $0.6,0.6$ to 10 and $>10 \mu \mathrm{m})$, microphytoplankton accounts for 70 to $100 \%$ of primary production during a bloom (chl a $>3 \mu \mathrm{gl} \mathrm{l}^{-1}$ ) but only for 20 to $60 \%$ before or even between blooms (Breton et al. unpubl.). Such a result is consistent, for instance, with D'Elia et al. (1983) who found diatoms accounted for only $50 \%$ of the primary production on an annual basis. Thus, each value of IPP, calculated in Step 1, has then been converted into an IPP due to diatoms using 1 of the 2 ranges given above, depending on whether the chl a concentration was higher or lower than $3 \mu \mathrm{g} \mathrm{l}^{-1}$. In keeping with the preceeding example, IPP calculated on 30 April in the 0 to $5 \mathrm{~m} \mathrm{sec}$ tion $\left(125.7 \pm 5.9 \mathrm{mmol} \mathrm{C} \mathrm{m}^{-2} \mathrm{~d}^{-1}\right)$ has been converted into the range $101 \pm 23 \mu \mathrm{mol} \mathrm{C} \mathrm{m}^{-2} \mathrm{~d}^{-1}$ (70 to $100 \%$ of IPP was due to microphytoplankton and $94 \%$ of the latter was due to diatoms). The use of 1993 data to estimate the contribution of diatoms to the spring 1992 primary production is supported by the fact that both specific compositions of phytoplankton exhibited similar dominance during the beginning of the 1992 and 1993 succession: both populations were dominated by Thalassiosira sp. and Skeletonema costatum during the early stage of the succession and then by Rhizosolenia sp. by mid-spring. In the light of this comparison, it is reasonable to use size-fractionation experiments performed during spring 1993, at least during the first 2 periods. During the 1992 late spring period, the phytoplankton-specific composition was strongly dominated by Chaetoceros sociale (see 'Results') and we considered that this diatom accounted for more than $70 \%$ of the carbon primary production during the whole late spring period. 
Step 3. Time-integration of IPP due to diatoms over each period. Time-integration of the depth-integrated primary production due to diatoms led to a carbon primary production given in $\mathrm{mol} \mathrm{C} \mathrm{m}^{-2}$ for the early spring, mid-spring and late spring periods. Final ranges in each horizontal section are given Table 3 for each of the 3 periods already defined.

Step 4. Space-integration over the whole Bay of Brest. In each horizontal section, the final range of space and time carbon primary production $(\mathrm{Mmol} \mathrm{C}=$ $10^{6} \mathrm{~mol} \mathrm{C}$ ) is calculated by multiplying the time-integrated carbon primary production due to diatoms and the area of the section concerned (Table 3). Summing the results obtained in the $4 \mathrm{sec}$ tions provides a range for the whole water column. Extrapolation to the whole Bay is reasonable since Box 6 (1) exhibits little horizontal and vertical variability and (2) accounts for $80 \%$ of the total Bay volume (see 'Sampling strategy').

Step 5. Conversion into a biogenic silica production. A range of BSi production (Mmol Si) was finally estimated after conversion of the final total (i.e. depth-, time- and space-integrated) carbon primary production due to diatoms (Mmol C) using appropriate $\mathrm{Si}$ : C molar ratios determined by Brzezinski (1985). An average ratio of $0.13 \pm 0.04$ was used for the first 2 periods dominated by siliceous microphytoplankton, and of $0.09 \pm 0.03$ for the last period dominated by siliceous nanophytoplankton.

Our estimates for the silica production during spring 1992 in the Bay of Brest range between 7 and $39 \mathrm{Mmol}$ Si for the early spring period, 22 and $85 \mathrm{Mmol} \mathrm{Si}$ for the mid-spring period, and 9 and $40 \mathrm{Mmol} \mathrm{Si}$ for the late spring period (Table 3). This leads to a total silica production ranging between 38 and $164 \mathrm{Mmol}$ Si during spring 1992. It is important to note that although first order approximation, our estimates for biogenic silica production are reasonable with respect to the rates that have been measured in other coastal ecosystems. Thus, between 6 April and 16 June, the mean spring biogenic silica production of the Bay of Brest was $13 \mathrm{mmol} \mathrm{Si} \mathrm{m} \mathrm{m}^{-2} \mathrm{~d}^{-1}$. This value is comparable to the one obtained in the Southeast Bering Sea $(17.7 \mathrm{mmol} \mathrm{Si}$ $\mathrm{m}^{-2} \mathrm{~d}^{-1}$ for the spring/summer period, Banahan \& Goering 1986). It is 2 times lower than that obtained during spring in the Northwest Africa and the Peru upwelling regions $\left(22 \mathrm{mmol} \mathrm{Si} \mathrm{m} \mathrm{m}^{-2} \mathrm{~d}^{-1}\right.$, Nelson \& Goering 1978; $27 \mathrm{mmol} \mathrm{Si} \mathrm{m}^{-2} \mathrm{~d}^{-1}$. Nelson et al. 1981, respectively) where carbon primary production (mean value

Table 3. Calculation of the silica production for the early, mid and late spring periods (Steps 3 to 5, 'Discussion'). Si:C ratios of $0.13 \pm 0.04$ (early, mid-spring) and $0.09 \pm 0.03$ (late spring) have been used for the conversion of time and space interated IPP into silica production

\begin{tabular}{|c|c|c|c|c|}
\hline \multirow{2}{*}{$\begin{array}{l}\text { Depth } \\
\text { (m) }\end{array}$} & \multirow{2}{*}{$\begin{array}{l}\text { Section } \\
\text { area } \\
\left(10^{6} \mathrm{~m}^{2}\right)\end{array}$} & \multicolumn{2}{|c|}{ IPP due to diatoms } & \multirow{2}{*}{$\begin{array}{l}\text { Biogenic silica } \\
\text { production } \\
\left(10^{6} \mathrm{~mol} \mathrm{Si}\right)\end{array}$} \\
\hline & & $\begin{array}{c}\text { Time } \\
\text { integrated } \\
\left(\operatorname{mol} \mathrm{Cm}^{-2}\right)\end{array}$ & $\begin{array}{c}\text { Time and space } \\
\text { integrated } \\
\left(10^{6} \mathrm{~mol} \mathrm{C}\right)\end{array}$ & \\
\hline \multicolumn{5}{|c|}{ Early spring, 06 to 23 Apr 1992} \\
\hline $0-5$ & 158.8 & $0.3-0.8$ & $48-127$ & $4-22$ \\
\hline $5-10$ & 85.7 & $0.2-0.6$ & $17-51$ & $2-9$ \\
\hline $10-20$ & 63.4 & $0.2-0.7$ & $13-44$ & $1-7$ \\
\hline \multirow[t]{2}{*}{$20-40$} & 23.1 & $0.0-0.2$ & $0-5$ & $0-1$ \\
\hline & & & & $7-39$ \\
\hline \multicolumn{5}{|c|}{ Mid-spring, 23 Apr to 20 May 1992} \\
\hline $0-5$ & 158.8 & $0.9-1.7$ & $143-270$ & $13-46$ \\
\hline $5-10$ & 85.7 & $0.7-1.4$ & $60-120$ & $5-20$ \\
\hline $10-20$ & 63.4 & $0.7-1.6$ & $44-101$ & $4-17$ \\
\hline \multirow[t]{2}{*}{$20-40$} & 23.1 & $0.1-0.4$ & $2-9$ & $0-2$ \\
\hline & & & & $22-85$ \\
\hline \multicolumn{5}{|c|}{ Late spring, 20 May to 16 Jun 1992} \\
\hline $0-5$ & 158.8 & $0.6-1.1$ & $95-175$ & $6-21$ \\
\hline $5-10$ & 85.7 & $0.4-1.0$ & $34-86$ & $2-10$ \\
\hline $10-20$ & 63.4 & $0.3-1.0$ & $19-63$ & $1-8$ \\
\hline \multirow[t]{2}{*}{$20-40$} & 23.1 & $0.0-0.3$ & $0-7$ & $0-1$ \\
\hline & & & & $9-40$ \\
\hline
\end{tabular}

Table 4. Silicic acid supplies to the surface layer of the Bay of Brest during spring 1992 (early, mid-and late spring) and subsequent fate of the biogenic silica produced during the same 3 periods. All data in $\mathrm{Mmol} \mathrm{Si}\left(10^{6} \mathrm{~mol} \mathrm{Si}\right)$

\begin{tabular}{|c|c|c|c|c|c|c|}
\hline \multirow{2}{*}{$\begin{array}{l}\text { Spring } \\
\text { period }\end{array}$} & \multicolumn{6}{|c|}{ Silicic acid supply (Mmol Si) } \\
\hline & $\begin{array}{l}\text { Pre-spring } \\
\text { stock }\end{array}$ & Rivers & Iroise & Sediment & Total & $\begin{array}{l}\text { Water column } \\
\text { recycling }\end{array}$ \\
\hline Early & 4 & 5 & 2 & $1-3$ & $12-14$ & $0-27$ \\
\hline Mid- & - & 8 & 1 & $3-7$ & $12-16$ & $6-73$ \\
\hline Late & - & 4 & 2 & $5-13$ & $11-19$ & $0-29$ \\
\hline Total & - & 17 & 5 & $9-23$ & $35-49$ & $6-129$ \\
\hline \multirow{2}{*}{$\begin{array}{l}\text { Spring } \\
\text { period }\end{array}$} & \multicolumn{6}{|c|}{ Fate of biogenic silica (Mmol Si) } \\
\hline & \multicolumn{2}{|c|}{$\begin{array}{l}\text { Water column } \\
\text { recycling }\end{array}$} & Advect & \multicolumn{2}{|c|}{ Deposition } & $\begin{array}{l}\text { Net } \\
\text { accumulation }\end{array}$ \\
\hline Early & \multicolumn{2}{|c|}{$0-27$} & 2 & \multicolumn{2}{|c|}{$5-10$} & $2-9$ \\
\hline Mid- & \multicolumn{2}{|c|}{$6-73$} & 3 & \multicolumn{2}{|c|}{$9-13$} & $2-10$ \\
\hline Late & \multicolumn{2}{|c|}{$0-29$} & 4 & \multicolumn{2}{|c|}{$5-7$} & $0-2$ \\
\hline Total & \multicolumn{2}{|c|}{$6-129$} & 9 & \multicolumn{2}{|c|}{$19-30$} & $4-21$ \\
\hline
\end{tabular}


ca $3 \mathrm{~g} \mathrm{C} \mathrm{m}^{-2} \mathrm{~d}^{-1}$, Jacques \& Tréguer 1986) is about 3 times higher than that of the Bay of Brest (mean value ca $0.8 \mathrm{~g} \mathrm{C} \mathrm{m}^{-2} \mathrm{~d}^{-1}$; Quéguiner 1982)

\section{Calculations of silicic acid inputs}

The demand of silicic acid by siliceous phytoplankton has to be balanced by available silicic acid. The latter represents the sum of the pre-spring silicic acid stock and of the silicic acid inputs from various origins (rivers and the adjacent Iroise Sea) and processes (benthic supply and recycling of silicic acid within the water column) during the study period (Table 4, silicic acid supply). Calculations for each source were made as follows:

Silicic acid pre-spring stock. This stock is calculated taking into account the volume of the Bay of Brest $\left(1.3 \times 10^{9} \mathrm{~m}^{3}\right)$ and an average pre-spring concentration of $3 \mu \mathrm{M}$ Si (Fig. 4).

Riverine supply. The riverine supply of nutrients into the Bay was calculated for Aulne and Elorn Rivers by multiplying river flows and the freshwater nutrient concentrations (between 150 and $200 \mu \mathrm{M}$ in both rivers during winter and between 80 and $150 \mu \mathrm{M}$ during spring).

Benthic supply. Estimates for the total benthic silicic acid supply for the whole Bay of Brest are based on extrapolation of the data obtained for Stn F in silt/sand sediments (Table 1), assuming the sedimentation of silica from diatom blooms is homogeneously distributed over the Bay. The fact that cores were taken in such a sediment which contains a large fraction of silicate minerals (30\% quartz, $10 \%$ clay minerals) does not influence the measured silicic acid flux, since this one is provided by dissolution of biogenic siliceous tests and not by dissolution of mineral silicate (Douchement 1987). In the first centimeter of sediment, silicic acid concentrations in pore waters were between $100 \mu \mathrm{M} \mathrm{Si}$ in April and $200 \mu \mathrm{M}$ Si in June (Douchement 1987), i.e. within a range of concentrations which are saturating with respect to the mineral phases, but below saturation with respect to biogenic amorphous silica (Siever 1962, Stober 1967. Yamada \& D'Elia 1984).

Silicic acid supply from the ocean. Depletion of silicic acid in the Bay of Brest usually occurs before that of the Iroise Sea, where unfavourable conditions for phytoplankton growth prevail late in the season (Delmas \& Tréguer 1983) due to intense mixing by strong tidal currents. Therefore during spring, silicic acid concentration is always higher in the Iroise Sea than in the Bay so that the exchange between the 2 ecosystems leads to a net input of silicic acid into the bay. An estimate of this net Iroise Sea input of silicic acid is calculated using a simple model (Berthois \& Auffret 1970) to quantify the exchanges of water and dissolved matter between the Bay and the Iroise Sea. For mean tide conditions the volume percent of the Bay of Brest renewed by Iroise Sea water averages $2.2 \%$ (Delmas 1981). The amount of silicic acid introduced in the Bay at each tide is given by:

$$
Q_{\mathrm{Si}}=\left(\left[\mathrm{Si}(\mathrm{OH})_{4}\right]_{1}-\left[\mathrm{Si}(\mathrm{OH})_{4}\right]_{\mathrm{B}}\right) \times 0.022(V+M)
$$

where $Q_{S i}=$ amount of Si (mol Si) introduced in the Bay during 1 tide; $\left[\mathrm{Si}(\mathrm{OH})_{4}\right]_{l}=$ average silicic acid concentration $\left(\mathrm{mmol} \mathrm{m}^{-3}\right)$ in the Iroise Sea $\left[\mathrm{Si}(\mathrm{OH})_{4}\right]_{\text {, }}$, estimated from the RNO (Réseau National d'Observation de la Qualité du Milieu Marin) data set (200 unpublished data from 1974 to 1992), decreased from 2.6 $\mu \mathrm{M}$ Si in April to $1.3 \mu \mathrm{M}$ Si in June; $\left[\mathrm{Si}(\mathrm{OH})_{4}\right]_{B}=$ average silicic acid concentration ( $\mathrm{mmol} \mathrm{m} \mathrm{m}^{-3}$ ) in the Bay of Brest, decreased from 1.3 $\mu \mathrm{M}$ Si in April to $0.6 \mu \mathrm{M} \mathrm{Si}$ in June; $V=$ volume of the Bay of Brest at low tide $(1.3 \times$ $\left.10^{9} \mathrm{~m}^{3}\right)$; and $M=$ volume oscillating between the Iroise Sea and the Bay at each tide $\left(1 \times 10^{9} \mathrm{~m}^{3}\right)$.

During each period, the total amount of silicic acid entering the Bay of Brest is $2 \mathrm{n} Q_{\mathrm{Si}}$ ( $\mathrm{n}=$ no. of days during the period; 2 tides $\mathrm{d}^{-1}$ ).

Table 4 compiles the different supplies of silicic acid (Mmol Si) to the Bay of Brest. Only the uncertainties concerning the benthic flux (Table 1) have been taken into account. Uncertainties concerning the pre-spring stock and the riverine and oceanic supplies have been neglected: silicic acid concentration is determined with a precision of $0.05 \mu \mathrm{M}$, river flows are given with a precision better than $5 \%$ and the exchange model of Delmas allows estimates of salinity which agree very well with measured values (maximum deviation is $0.06 \mathrm{PSU}$ at the 35 PSU level).

\section{Estimate of the recycling within the water column}

Recycling of silicon within the water column is obtained during each of the 3 periods, by substracting the sum of the different silicic acid inputs from the silica production (Table 4). During the early spring period for example, silicic acid inputs (12 to $14 \mathrm{Mmol}$ Si) may have sustained all the silica production, if the latter was within the bottom of the range ( 7 to $14 \mathrm{Mmol}$ $\mathrm{Si}$ ); but if the silica production was $39 \mathrm{Mmol} \mathrm{Si}$ (the highest value of the range of silica production during that period, Table 3), then an additional $27 \mathrm{Mmol}$ Si are required if the inputs were only $12 \mathrm{Mmol} \mathrm{Si}$. It is important to note that in spite of relatively large uncertainties concerning the estimate of the silica production, it can be no doubt concluded that by mid-spring, silicic acid inputs (12 to $16 \mathrm{Mmol} \mathrm{Si}$ ) were not sufficient to sustain the diatom requirement (22 to $85 \mathrm{Mmol}$ Si) so 
that a minimum of $6 \mathrm{Mmol}$ Si was necessarily provided by dissolution of biogenic silica in the water column.

\section{The fate of biogenic silica}

The biogenic silica which does not dissolve within the water column is either advected out of the Bay, or it settles down to the floor of the Bay. The latter fraction is then either incorporated into the sediments or it dissolves to bring back silicic acid to the water column. Fluxes of biogenic silica (Table 4) were calculated as follows:

Advection out of the bay. Quéguiner (1982) already reported the export of production out of the Bay during spring contrasting with the import of silicic acid. The advective flux of biogenic silica that leaves the Bay during 1 tide has been calculated the same way as the supply of silicic acid from the Iroise Sea, using Eq. (2):

$$
Q_{\mathrm{BSi}}=\left([\mathrm{BSi}]_{\mathrm{I}}-[\mathrm{BSi}]_{\mathrm{B}}\right) \times 0.022(V+M)
$$

where $[\mathrm{BSi}]_{\mathrm{B}}=$ biogenic silica concentration measured in the Bay of Brest; $\left[\mathrm{BSi}_{1}=\right.$ biogenic silica concentration of the Iroise Sea; $V$ and $M$ are as in Eq. (1).

This flux is a maximal estimate, since $[B S i]_{t}$ is assumed to be zero because of the conditions prevailing in the Iroise Sea at this time of the year (see above).

Silica deposition. This flux is estimated by substraction of BSi dissolution and advection fluxes from BSi production.

Net accumulation. Incorporation within sediments is estimated by substraction of the benthic silicic acid flux we measured from the estimate of the silica deposition.

Table 5. Relative contributions (\% silica production) of the different silicic acid supplies and subsequent fate (\% silica production) of the biogenic silica produced during the 3 periods of spring 1992

\begin{tabular}{|c|c|c|c|c|c|c|c|}
\hline \multirow{2}{*}{$\begin{array}{l}\text { Spring } \\
\text { period }\end{array}$} & \multirow{2}{*}{$\begin{array}{c}\text { Silica } \\
\text { production } \\
\text { (Mmol Si) }\end{array}$} & \multicolumn{6}{|c|}{ Silicic acid supply (\% silica production) } \\
\hline & & $\begin{array}{l}\text { Pre-spring } \\
\text { stock }\end{array}$ & Riv & rers & Iroise & Sediment & $\begin{array}{l}\text { Water column } \\
\text { recycling }\end{array}$ \\
\hline Early & $7-39$ & $34 \pm 24$ & $42 \pm$ & 29 & $17 \pm 12$ & $23 \pm 20$ & $35 \pm 35$ \\
\hline Mid- & $22-85$ & - & $23 \pm$ & $=14$ & $3 \pm 2$ & $18 \pm 14$ & $57 \pm 30$ \\
\hline Late & $9-40$ & - & $27 \pm$ & 17 & $14 \pm 9$ & $57 \pm 44$ & $37 \pm 37$ \\
\hline Total & $38-164$ & $7 \pm 5$ & $28 \pm$ & 18 & $9 \pm 4$ & $33 \pm 28$ & $48 \pm 32$ \\
\hline \multirow{2}{*}{$\begin{array}{l}\text { Spring } \\
\text { period }\end{array}$} & \multirow{2}{*}{$\begin{array}{c}\text { Silica } \\
\text { production } \\
\text { (Mmol Si) }\end{array}$} & \multicolumn{6}{|c|}{ Fate of biogenic silica ( $\%$ silica production) } \\
\hline & & $\begin{array}{l}\text { Water coll } \\
\text { recyclin }\end{array}$ & umn & Adv & ection & Deposition & $\begin{array}{c}\text { Net } \\
\text { accumulation }\end{array}$ \\
\hline Early & $7-39$ & $35 \pm 35$ & & 17 & \pm 12 & $49 \pm 23$ & $26 \pm 3$ \\
\hline Mid- & $22-85$ & $57 \pm 30$ & & & \pm 5 & $35 \pm 24$ & $11 \pm 2$ \\
\hline Late & $9-40$ & $37 \pm 37$ & & 27 & \pm 17 & $37 \pm 19$ & $3 \pm 3$ \\
\hline Total & $38-164$ & $48 \pm 32$ & & & \pm 10 & $46 \pm 34$ & $29 \pm 27$ \\
\hline
\end{tabular}

\section{Silicon balance during spring 1992}

The relative contributions of the various silicic acid sources to the BSi production and of the different pathways of transformation of the BSi produced are presented in Table 5. Three major observations can be made, which will drive the subsequent discussion. The first bloom during early spring was sustained by almost only riverine inputs (including the pre-spring stock) and the major fraction of the silica produced was deposited on the Bay floor and then incorporated within the sediment. The second bloom during midspring was mainly supported by silicic acid regenerated within the water column. The last bloom was sustained by benthic silicic acid regeneration which strongly increased during this warm pre-summer period, leading to a strong decrease of the net accumulation of BSi in the sediment, as compared to that of the early spring.

Our estimate for the contribution of internal recycling in the water column during the early spring period lies within a wide range ( 0 to $70 \%)$. The upper limit of the range is not realistic since: (1) exponentially growing populations can release silicic acid to the medium by dissolution at rates ranging only from 6.5 to $15 \%$ of the maximum uptake rate (Nelson et al. (1976); (2) this is the first bloom so that detrital biogenic silica which may dissolve at higher rates concentration must be small; and (3) the temperature is low (around $10^{\circ} \mathrm{C}$ ) which, according to Kamatani (1982), is unfavourable to rapid redissolution of biogenic silica. The overestimate of the contribution of silicic acid recycling within the water column during early spring could arise from the use of $\mathrm{Si}: \mathrm{C}$ ratios which are too high in the estimate of the silica production. Actually, at the end of the early spring period, silicic acid concentrations were at their mimimum, close to limiting levels for diatom growth (Guillard et al. 1973). Under such conditions, diatoms are known to construct thinner frustules (Paasche 1973a) which would result in lowering BSi:POC ratios as compared to the average ratio we used, measured by Brzezinski (1985) for nutrient-replete diatoms.

The decreasing influence of the recycling within the water column between mid- and late spring could appear as a paradox, because of the $3^{\circ} \mathrm{C}$ increase in temperature observed meanwhile which would have enhanced the dissolution rate by around 30\% (Kamatani 1982). This point will be further discussed. 


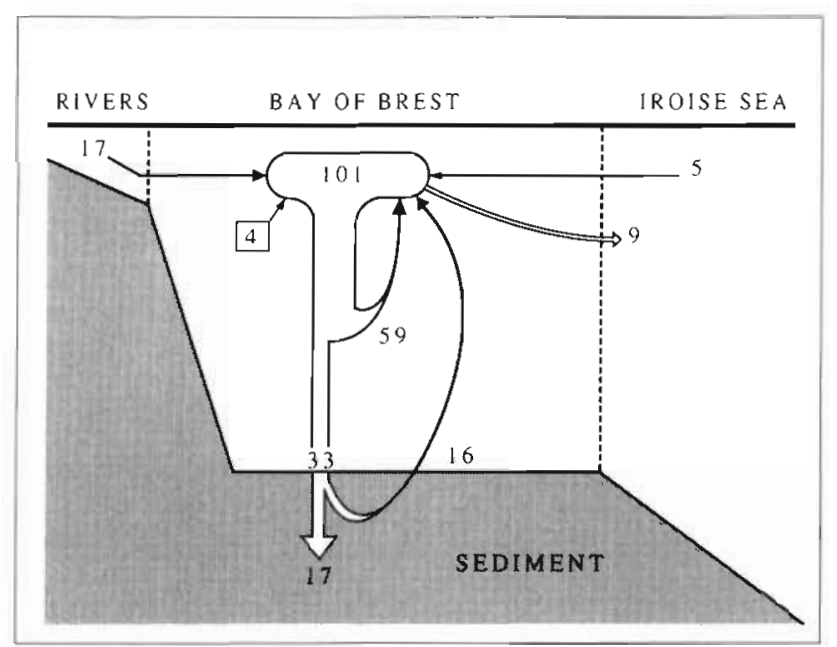

Fig. 8. Silicon balance during spring 1992 in the Bay of Brest system (all fluxes in Mmol Si). Contributions of the different silicic acid supplies $(\longrightarrow$ ) to the mean spring silica production (101 Mmol Si), and different pathways taken by the biogenic silica $(\Longrightarrow$ produced. $=\stackrel{\longrightarrow}{\longrightarrow}$ indicates dissolution processes

Fig. 8 provides a synthetic view of the silicon balance during spring 1992 in the Bay of Brest. It is one possible scenario, where silica production and benthic flux are chosen as the mean of the ranges we calculated. Recycling in the water column, deposition and accumulation are derived by the same calculation as that already described. Note that silica production is close to $100 \mathrm{Mmol} \mathrm{Si}$ so that all fluxes, expressed in $\mathrm{Mmol} \mathrm{Si}$, can also be read as \% of the silica production. Only $4 \%$ of the diatom requirement are provided by the pre-spring standing stock of silicic acid while almost one-fifth comes from new riverine inputs during spring. This highlights the importance of the precipitation regime during spring, rather than during the precedent winter, in the control of the magnitude of the spring bloom [see Conley \& Malone (1992) for a similar result in the Chesapeake Bay]. The sum of the silicic acid pre-spring stock and oceanic supplies contributes to a small extent (9 Mmol Si) to the whole spring silica production, and finally accounts for all the biogenic silica exported to the adjacent ocean. Some $16 \mathrm{Mmol} \mathrm{Si}$ is due to silicic acid regenerated within the sediment which is comparable to the contribution of the watershed $(17 \mathrm{Mmol} \mathrm{Si})$. This is an illustration of the equal importance of silicic acid fluxes from the sediment and from terrestrial drainage, reported by Spencer (1983) at a global scale as the most striking more recent contribution to our knowledge of the biogeochemical cycle of silicon in sea water'. The high contribution of the recycling within the water column (59\%) also shows that the sediment, although very important in the regeneration of silicic acid during late spring (Table 5), is not the only site of biogenic silica dissolution in coastal waters. A quite similar contribution $(69 \%)$ has been obtained for water column recycling in Lake Michigan by Conley et al. (1988).

This balance also shows that half of the silica deposited on the floor of the Bay of Brest by the sedimentation of diatom blooms is incorporated within the sediment. This net silica accumulation (net sink) which represents almost one-fifth of the spring silica production matches the fluvial silicic acid inputs (net source). Even if it can be supposed that a significant fraction of this net spring sink will return to the water column during summer, it is interesting to note that this result, on a seasonal scale, is consistent with findings of DeMaster (1981) in Long Island Sound and D'Elia et al. (1983) in Chesapeake Bay, where calculations were made on an annual basis.

The silicon balance we present here is subject to uncertainties. They principally arise (1) from the indirect estimate of the silica production which required many steps and (2) from the estimates of water column recycling as well as silica deposition and accumulation, using the differences between measured and estimated fluxes. However, the budget presented seems reasonable and is the best estimate that can actually be made. It will have to be compared with another approach involving direct measurements of biogenic silica production and dissolution, using isotopic methods (Nelson \& Goering 1977. Nelson \& Gordon 1982, Tréguer et al. 1991) that have not yet been used in coastal areas, except in upwelling regions.

\section{Control of the dynamics of phytoplankton by the silicon cycle}

Continous enrichment of some coastal waters by $N$ and $\mathrm{P}$ compounds has been observed for several decades (review in Smayda (1990) for European countries]. The Bay of Brest is typical of this situation, with freshwater nitrate concentrations raising from $50 \mu \mathrm{M}$ at the beginning of the century to over $450 \mu \mathrm{M}$ nowadays (Tréguer \& Quéguiner 1989). This has resulted in long-term declines of $\mathrm{Si}: \mathrm{N}$ and $\mathrm{Si}: \mathrm{P}$ nutrient ratios, since silicic acid concentration in river waters, controlled by natural processes, remained almost constant over decades $(150 \mu \mathrm{M})$. The hypothesis that silicic acid (and not nitrate) has now become the first limiting factor of the spring blooms in those coastal waters has emerged (review in Smayda 1990). The Bay of Brest is a good candidate to test this hypothesis, especially during the first phase of the bloom period when the riverine inputs (including the pre- 
spring stock) represent the major part of the nutrients available for phytoplankton growth (see 'Silicon balance', Fig. 8).

\section{Early spring bloom: the major role of silicic acid river} supply

In the absence of major meteorological events, the decrease in every biomass index after the first spring bloom can be the result of heavy grazing by zooplankton or nutrient limitation of the phytoplankton growth itself. A characteristic feature of temperate water spring blooms is the absence of large zooplankton populations, at least during the early stage of the phytoplankton development (Smetacek 1980a) and this has been commonly observed in the Bay of Brest (Quéguiner 1982, Hafsaoui et al. 1985). So, it is unlikely that zooplankton could have played a major role in the control of phytoplankton biomass and production during this period. Thus, the question of the nutrient limitation has to be addressed.

Limitation of diatom growth by nitrate or phosphate deficiency seems unlikely, for 2 reasons. (1) Diatoms use silicon in approximately a 1:1 atomic ratio with nitrogen (Redfield et al. 1963). As far as river discharges are concerned, nitrate inputs into the Bay of Brest are about 5 times larger than silicic acid inputs so that during early spring nitrate is still available in surface waters when silicic acid has dramatically decreased (Fig. 4). (2) Desorption of phosphate from lithogenic suspended matter is known to account for an extra flux of available dissolved phosphorus for phytoplankton demand and Delmas (1981) showed that phosphate should not limit phytoplankton growth, at least during the first phase of the blooming period.

We hypothesize Si could be the major limiting factor for diatom growth in early spring. When biogenic silica reached its maximum at $1.8 \mathrm{\mu mol} \mathrm{BSi} \mathrm{l}^{-1}$, surface silicic acid concentrations had decreased to $0.5 \mu \mathrm{M}$ (Fig. $4 \mathrm{a}$ ), i.e. below levels that are usually considered to limit silicic acid uptake (Paasche 1973a, b, Conway \& Harrison 1977) and diatom growth (Guillard et al. 1973) in temperate waters. Officer \& Ryther (1980) demonstrated that low silicic acid supplies relative to uptake rates by diatoms can limit increases in diatom biomass or growth rate. As a result of high sinking rates of silicic acid-deficient populations (Bienfang et al. 1982) a decline of diatom biomass is observed. The apparent absence of aggregates in the Bay of Brest during early spring indicates that the buoyancy of diatoms might be physiologically controlled (Bienfang 1981) so that ungrazed diatom blooms may settle down after nutrient depletion of the surface layer. Conley \& Malone (1992) recently hypothesized that the collapse of a spring bloom in Chesapeake Bay occurred as a consequence of silicic acid deficiency and associated increases in sedimentation rates. Such a mass sinking of diatoms has been considered as a survival strategy (Smetacek 1985) as formation of resting spores, not necessarily triggered by $\mathrm{N}$-deficiency, is often involved in the explanation of enhanced sedimentation rates (Hargraves \& French 1983). Indices of a mass sinking of diatoms in the Bay of Brest come from the examination of the silicon balance. The highest silica deposition (Table 5) is observed in early spring, corresponding to a large increase in the BSi content of the sediment: from $0.36 \%$ in March to about $1 \%$ in April (Table 1). Thus, due to this Si limitation, up to $72 \%$ of the silica produced in April could have escaped the water column of the Bay of Brest (Table 5).

As a consequence of the diatom decline, a shift from a diatom-dominated community to a planktonic community dominated by bacteria and nondiatomaceous species [similar to the one reported in the Chesapeake Bay by Malone et al. (1991) and in other coastal areas, review in Smayda (1990)] was expected to occur in the Bay. Such a change was observed on 16 April in the Bay of Brest (Fig. 7) but it was small, brief and probably without major impact on the following spring diatom succession. Hydrodynamic conditions (enhanced tidal mixing (16 April; Fig. 2) at the end of the first bloom) were clearly responsible for this, since stable physical conditions are required to allow the development of dinoflagellates (Margalef 1978). Si deficiency then appears as responsible for the collapse of the diatom bloom, whereas enhanced vertical mixing might have precluded the emergence of a dinoflagellate population.

\section{Mid-spring bloom: the dominant influence of the silicic acid recycling in the water column}

By mid-spring, diatom biomass remained at a high level in spite of silicic acid concentrations lower than $1 \mu \mathrm{M}$. The silicon balance suggests that Si recycling might have controlled the biomass level between 30 April and 14 May, as long as regeneration proceeded at rates fast enough to counter-balance losses by sedimentation and grazing. The end of the midspring period was marked by a collapse in the diatom domination after the second bloom: on 20 May, the concentration of dinoflagellates overwhelmed that of diatoms and the diatom:dinoflagellate ratio decreased down to 0.5 (Fig. 7). Unlike dinoflagellate cell concentration, which increased between 14 and 20 May, that of diatoms strongly decreased. Since nitrate concentrations were still high, this could be interpreted again as a consequence of limitation by silicic acid, because 
diatom standing stocks cannot be maintained indefinitely by in situ dissolution of biogenic particulate silica (Brzezinski 1987). The collapse of the diatom bloom could also reflect the influence of mesozooplankton grazing, a hypothesis which is consistent with the previous observations of Quéguiner (1982) in the Bay of Brest; from late April to mid-May 1982, i.e. about 2 wk after a phytoplankton bloom, he observed a strong increase in mesozooplankton biomass which dramatically reduced the chl a standing crop. Thus, mesozooplankton grazing may have contributed to the decrease of diatom biomass without affecting the dinoflagellates which are often considered as poor foods for most grazers (Officer \& Ryther 1980).

Mesozooplankton grazing would also provide an explanation for the increased BSi recycling within the water column (Table 5a), although this particular effect is still a matter of debate. Smayda (1970) has demonstrated that zooplankton grazing contributes to increase the sedimentation of frustules through its heavier faecal pellets, but Bishop et al. (1986) have shown that recycling of material was enhanced in the upper meters of the water column due to zooplankton activity. Smetacek (1980a, b) has observed a minimum in the sedimentation rate during a maximum in copepod biomass for the shallow waters of the Kiel Bight, Germany; he then speculated that grazing retards, rather than accelerates, vertical flux of biogenic silica, because faecal pellets tend to be recycled within the surface layer by the common herbivorous copepods or by bacterial decomposition (Smetacek 1985). Together with zooplankton activity, temperature probably played a major role in the $\mathrm{BSi}$ dissolution: according to Kamatani (1982) the $3^{\circ} \mathrm{C}$ increase that occurred between early and mid-spring is sufficient to enhance dissolution rates by ca $30 \%$. Of course, the presence of the siliceous biogenic matter produced during the early spring bloom is of primary interest when explaining that $57 \pm 30 \%$ of the silica production during the second bloom comes from dissolution within the water column. There are different sources of dissolving silica in the photic layer: according to Van Lier et al. (1960), in usual conditions prevailing in coastal waters the kinetics of dissolution of suspended silicate minerals are too slow to produce a measurable amount of silicic acid, and thus the main sources of recycled silicic acid in the water column come from suspended biogenic siliceous matter. Settling senescent diatoms or resting stages and settling empty frustules (free-floating or within faecal material) make significant contribution to Si internal recycling. Diatom frustules resuspended from the sediment by wind-driven mixing or during an $\mathrm{M}_{2}$ tidal cycle (Demers et al. 1987) might also represent an important source of dissolving material in the shallow waters of the Bay of Brest.

\section{Late spring bloom: the major role of silicic acid benthic regeneration}

The contribution of Si recycling within the water column to the silica production of the last bloom was expected to increase at the end of the study period due to increased water temperature $\left(>16^{\circ} \mathrm{C}\right)$ and the presence of suspended biogenic silica generated during the 2 other blooms. Although remaining at high levels, this $\mathrm{Si}$ recycling pathway was overwhelmed by benthic regeneration during late spring (Table 5). Between 20 May and 4 June the nitrate concentration of surface waters decreased from 5 to $0 \mu \mathrm{M}$. Owing to logistical problems we have not been able to sample this period and we cannot preclude the development of a bloom which would have escaped our survey. So, the moder-

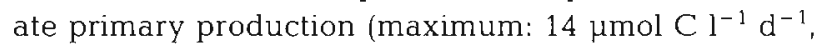
Fig. 5; lower silica production as compared to the midspring period, Table 3) we observed during this late spring period can be explained by remnant nutrientdepleted conditions $(<2 \mu \mathrm{M}$ for nitrate, $<0.1 \mu \mathrm{M}$ for phosphate, $<1 \mu \mathrm{M}$ for silicic acid). During this period, $\mathrm{Si}: \mathrm{N}$ and $\mathrm{Si}: \mathrm{P}$ nutrient molar ratios increased dramatically, reaching 14 and 24 respectively at their maximum, so that nitrogen deficiency may have limited phytoplankton growth. This $\mathrm{N}$ deficiency has already been observed during spring in the Bay of Brest (Dauchez et al. 1991) and is explainable both by decreasing riverine influence and by the still low ammonium/nitrate benthic fluxes at this time of the season, compared to summer (Souchu 1986).

Unlike nitrogen, silicon is actively regenerated at the water-sediment interface at the end of spring (Table 5). This silicic acid transfer to the water column enables some siliceous phytoplankton growth and a moderate monospecific development of Chaetoceros sociale reached its maximum on 16 June. C. sociale is a colony-forming diatom usually embedded in a gelatinous matrix (Alldredge \& Gotschalk 1989) and commonly observed in the Bay of Brest by late spring (Quéguiner \& Tréguer 1984). Within a nutrientdepleted bloom, colonies can sink differentially and become entangled together as they settle (Bienfang 1981; Smetacek 1985), a phenomenon which has been described at a larger scale for the Santa Barbara Channel (California, USA) by Alldredge \& Gotschalk (1989). In those circumstances sinking rates can be as high as $120 \mathrm{~m} \mathrm{~d}^{-1}$, i.e. the $C$. sociale colonies were able to reach the bottom of the shallow Bay of Brest in less than $1 \mathrm{~d}$. An important consequence of increased sedimentation is the delay in the replenishment of the euphotic layer in nutrients: aggregates transported biogenic silica to the bottom before it was grazed by zooplankton; thus, instead of being recycled within the water column, as during mid-spring, part of this 


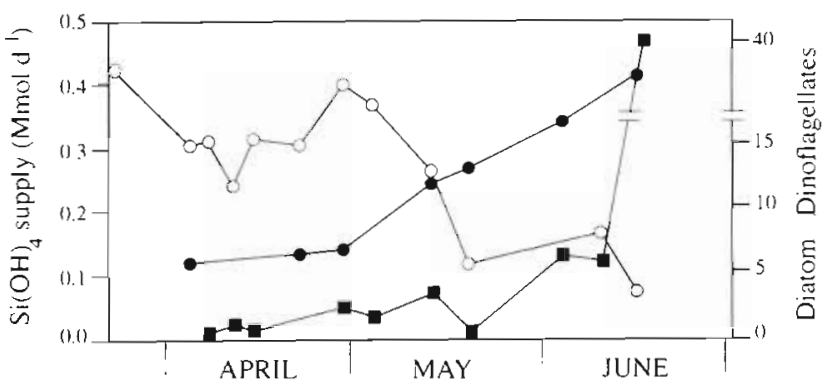

Fig. 9. Increasing diatom: dinoflagellate ratio (ロ) after midMay, when benthic silicic acid supply $(\bullet)$ overwhelmed the riverine silicic acid discharge (o) when different hydrodynamical situations will be encountered.

Acknowledgements. Part of this study comes within the framework of the 'Rade de Brest' project, a multidisciplinary research program supported by the 'Communauté Urbaine de Brest' The authors are particularly grateful to D. M. Nelson (Oregon State University) who provided very helpful comments on an earlier version of this manuscipt. We thank Anne Daniel and Annick Masson for their help at sea, as well as for nutrient analysis. We are very grateful to Alain Paimbéni for improvement of the figures. Thanks are also due to the crew of RV 'Ste Anne du Portzic' (GENAVIR). This study is contribution no. 94002 of URA CNRS 1513.

\section{LITERATURE CITED}

siliceous material reached the sediment (Table 5) where it was recycled at high rates because of the temperature effect. This recycled silicic acid was not available for phytoplankton as rapidly as it would have been if recycled within the water column; it would be upwelled only during the following spring tide period or the next wind-driven mixing event, exacerbating the lack in nutrients and lowering the silica production of this period. This phenomenon might explain the decreasing contribution of the recycling within the water column which was expected to increase between mid-and late spring (see above).

As a consequence of this high silicic acid regeneration rate, Fig. 9 clearly demonstrates the influence of increasing benthic regeneration on the diatom:dinoflagellate ratio, which also strongly rose at the end of the study period. Thus contrary to Wangersky (1977), in the conditions prevailing in the Bay of Brest, when in situ regeneration overwhelmed the riverine influence, flagellates did not become dominant over diatoms.

\section{CONCLUSION}

Silicic acid limitation was most likely to occur during the spring 1992 in the Bay of Brest when the silica production was essentially supported by river inputs. During this early spring period, the development of a dinoflagellate bloom was limited by unsuitable hydrographic conditions coincident with the termination of the diatom bloom. Then, when the silica production became supported by regenerated silicic acid, Si recycling appeared fast enough (first within the water column, then within the sediment) to sustain a diatombased carbon production. Thus, hydrodynamics and silicic acid regeneration appear as natural barriers preventing the development of nondiatomaceous species following silicic acid limitation. The relative importance of those 2 mechanisms has to be further explored
Alldredge, A. L., Gotschalk, C. C. (1989). Direct observations of the mass flocculation of diatom blooms: characteristics, settling velocities and formation of diatoms aggregates. Deep Sea Res. 36(2): 159-171.

Ambler, J. W., Cloern, J. E., Hutchinson, A. (1985) Seasonal cycles of zooplankton from San Francisco Bay. Hydrobiologia 129: 177-197

Banahan, S., Goering, J. J. (1986). The production of biogenic silica and its accumulation on the Southeastern Bering Sea Shelf. Cont. Shelf Res. 5: 199-213

Berthois, L., Auffret, G. (1970). Contribution à l'étude des conditions de sédimentation dans la Rade de Brest, Chap. Cah. Oceanogr. 10: 981-1009

Bienfang, P. K. (1981). Sinking rates of heterogeneous, temperate phytoplankton populations. J. Plankton Res. 3(2): 235-253

Bienfang, P. K., Harrison, P. J., Quarmby, L. M. (1982). Sinking rate response to depletion of nitrate, phosphate and silicate in four marine diatoms. Mar. Biol. 67: 295-302

Billen, G., Lancelot, C., Meybeck, M. (1991). N, P, and Si retention along the aquatic continuum from Land to Ocean. In: Mantoura, R. F. C., Martin, J.-M., Wollast, R. (eds.) Ocean margins processes in global change. J. Wiley \& Sons, New York, p. 19-44

Bishop, J. K. B., Conte, M., Wiebe, P. H., Roman, M. R., Langdon, C. (1986). Particulate matter production and consumption in deep mixed layers: observations in a warmcore ring. Deep Sea Res. 33: 1813-1841

Boynton, W. R., Garber, J. H., Barnes, J. M., Matteson, L., Stammerjohn, S., Watts, J. L. (1989). Ecosystem process report Level 1, Report 6 (UMCEES CBL Ref. No. 89-089). Maryland Department of the Environment, Baltimore interspecific variability and the effect of some environmental variables. J. Phycol. 21: 347-357

Brzezinski, M. A. (1987). Physiological and environmental factors affecting diatom species competition in a Gulf Stream warm-core ring. Ph.D. dissertation, Oregon State University, Corvallis

Brzezinski, M. Nelson, D. M. (1989). Seasonal change in the silicon cycle within a Gulf Stream warm-core ring. Deep Sea Res. 36: 1009-1030

Calvert, S. E. (1966). Accumulation of diatomaceous silica in the sediments of the Gulf of California. Bull. Geol. Soc. A.m. 77: 569-596

Calvert, S. E. (1983). Sedimentary geochemistry of silicon. In: Aston, S. R. (ed.) Silicon geochemistry and biogeochemistry. Academic Press, London, p. 101-141 4: étude analytique des apports fluviaux en Rade de Brest.

Brzezinski, M. A. (1985). The Si:C:N ratio of marine diatoms 
Conley, D. J., Malone, T. C. (1992). Annual cycle of dissolved silicate in Chesapeake Bay: implications for the production and fate of phytoplankton biomass. Mar. Ecol. Prog. Ser. 81: 121-128

Conley, D. J., Quigley, M. A., Schelske, C. L. (1988). Silica and phosphorus flux from sediments: importance of internal recycling in Lake Michigan. Can. J. Fish. Aquat. Sci. 45: $1030-1035$

Conway, H. L., Harrison, P. J (1977). Marine diatoms grown in chemostats under silicate or ammonium limitation. IV Transient response of Chaetoceros debilis, Skeletonema costatum and Thalassiosira gravida to a single addition of the limiting nutrient. Mar. Biol. 43: 33-43

Dauchez, S., Quéguiner, B., Tréguer, P., Zeyons, C. (1991). A comparative study of nitrogen and carbon uptake by phytoplankton in a coastal eutrophic ecosystem (Bay of Brest, France). Oceanol. Acta 14 (1): 87-95

D'Elia, C. F., Nelson, D. M., Boynton, W. R. (1983), Chesapeake Bay nutrient and plankton dynamics. III. The annual cycle of dissolved silicon. Geochim. Cosmochim. Acta 47: 1945-1955

Delmas, R. (1981). Etude de l'évolution saisonnière des sels nutritifs dans la Rade de Brest en fonction des apports fluviaux et des échanges avec l'Iroise. Thèse $3^{\text {ème }}$ cycle, Univ. de Bretagne Occidentale, Brest

Delmas, R., Tréguer, P. (1983). Evolution saisonnière des nutriments dans un écosystème eutrophe de l'Europe Occidentale (la Rade de Brest). Interactions marines et terrestres. Oceanol. Acta 6:345-356

Delmas, R, Tréguer, P. (1985). Simulation de l'évolution de paramètres physiques, chimiques, et de la biomasse phytoplanctonique en période printanière dans un écosystème littoral macrotidal. Oceanis 11 (3): 197-211

DeMaster, D. J. (1981). The supply and accumulation of silica in the marine environment. Geochim. Cosmochim. Acta 45: $1715-1732$

Demers, S., Therriault, J-C., Bourget, E., Abdourrahmane, B. (1987). Resuspension in the shallow sublittoral zone of a macrotidal estuarine environment: wind influence. Limnol. Oceanogr. 32(2): 327-339

Douchement, C. (1987). Chimie de deux milieux marins anoxiques: eaux hydrothermales et eaux interstitielles des sédiments. Méthodologie des prélèvements et des analyses des composés de l'azote, du phosphore et du silicium. Dynamique de leur circulation en sédiments côtiers. Thèse $3^{\text {eme }}$ cycle, Univ. de Bretagne Occidentale, Brest

Gucluer, S. M., Gross, M. G. (1964). Recent sediments in Saanich Inlet, a stagnant marine basin. Limnol. Oceanogr. 9: $359-376$

Guillard, R. R. L., Kilham, P., Jackson, T. A. (1973). Kinetics of silicon-limited growth in the marine Thalassiosira pseudonana Hasle and Heimdal (= Cyclotella nana Hustedt). J. Phycol. 9: 233-237

Hafsaoui, M. (1984). Fertilisation d'un système eutrophe à forte variabilité saisonnière et annuelle (rade de Brest) Mise en évidence des facteurs limitants de la production phytoplanctonique. Assimilation simultanée des différentes formes d'azote inorganique et organique. Thèse de $3^{\text {ème }}$ cycle, Université de Bretagne Occidentale, Brest

Hafsaoui, M., Quéguiner, B., Tréguer, P. (1985). Production primaire et facteurs limitant la croissance du phytoplancton en Rade de Brest. Oceanis 11 (3): 181-195

Hargraves, P., French, F. W. (1983). Diatom resting spores: significance and strategies. In: Fryxell, G. A. (ed.) Survival strategies of the algae. Cambridge University Press, Cambridge, p. $49-68$
Henriksen, K., Hansen, J. I., Blackburn, T H. (1981) Rates of nitrification of nitrifying bacteria, and nitrate fluxes in different types of sediment from Danish waters. Mar. Biol. 61: 299-304

Hily, C. (1991). Is the activity of benthic suspension feeders a factor controlling water quality in the Bay of Brest? Mar. Ecol. Prog. Ser. 69; 179-188

Jacques, G., Tréguer, P. (1986). Ecosystèmes pélagiques marins. Collection d'Ecologie 19. Masson, Paris

Kamatani, A. (1982). Dissolution rates of silica from diatom decomposing at various temperatures. Mar. Biol. 68: $91-96$

Koroleff, F. (1969). Direct determination of ammonia in natural waters as indophenol blue. Comm. Meet. int. Coun. Explor. Sea C.M.-ICES C9: 19-22

Malone, T. C., Ducklow, H. W., Peele, E. R. Pike, S. E. (1991). Picoplankton carbon flux in Chesapeake Bay. Mar. Ecol. Prog. Ser. 78: 11-22

Margalef, R. (1958). Temporal succession and spatial heterogeneity in phytoplankton. In: Buzzati-Traverso, A. A. (ed.) Perspectives in marine biology. University of California Press, Berkeley, p. 323-349

Margalef, R. (1978). Life-forms of phytoplankton as survival alternatives in an unstable environment. Oceanol. Acta 1: 493-509

Meybeck, M., Helmer, R. (1989). The quality of rivers: from pristine stage to global pollution. Paleogeogr. Paleoclim. Paleoecol. 75: 283-309

Mullin, J. B., Riley, J. P. (1965). The spectrophotometric determination of silicate-silicon in natural waters with special reference to seawater. Anal. Chim. Acta 46: 491-501

Murphy, J., Riley, J. P. (1962). A modified single solution method for the determination of phosphate in natural waters. Anal. Chim. Acta 27:31-36

Nedwell, D. B. (1982). Exchange of nitrate and the products of bacterial nitrate reduction between seawater and sediment from a U.K. saltmarsh. Estuar. coast. Shelf Sci. 14: $557-566$

Nelson, D. M., Goering, J. J. (1977). A stable isotope tracer method to measure silicic acid uptake by marine phyto. plankton. Analyt. Biochem. 78: 139-147

Nelson, D. M., Goering, J. J. (1978). Assimilation of silicic acid by phytoplankton in the Baja California and the Northwest Africa upwelling systems. Limnol. Oceanogr 23: 508-517

Nelson, D. M., Goering, J. J., Boisseau, D. W. (1981). Consumption and regeneration of silicic acid in three coastal upwelling systems. In: Richards, F. A. (ed.) Coastal upwelling. American Geophysical Union, Washington, DC, p. 242-256

Nelson, D. M., Goering, J. J., Guillard, R. R. L. (1976). Kinetics of silicic acid uptake and rates of silica dissolution in the marine diatom Thalassiosira pseudonana. J. Phycol. 12: 246-252

Nelson, D. M., Gordon, L. I. (1982). Production and pelagic dissolution of biogenic silica in the Southern Ocean. Geochim. Cosmochim. Acta 46: 491-501

Officer, C. B., Ryther, J. H. (1980). The possible importance of silicon in marine eutrophication. Mar. Ecol. Prog. Ser. 3: $83-91$

Paasche, E. (1973a). Silicon and the ecology of manine diatoms. I. Thalassiosira pseudonana (Cyclotella nana) grown in chemostats with silicate as the limiting nutrient. Mar. Biol. 19: 117-126

Paasche, E. (1973b). Silicon and the ecology of marine diatoms. II. Silicate-uptake kinetics in five diatom species. Mar. Biol. 19: 262-269 
Paasche, E., Ostergren, I. (1980). The annual cycle of plankton diatom growth and silica production in the inner Oslofjord. Limnol. Oceanogr. 25 (3): 481-494

Peterson, $W$. T (1986). The effects of seasonal variations in stratification on plankton dynamics in long island sound. In: Bowman, J., Yentsch, M., Peterson, W. T. (eds.) Tidal mixing and plankton dynamics. Springer-Verlag, Berlin, p. $297-320$

Pingree, R. D. (1978). Mixing and stabilization of phytoplankton distributions on-the Northwest European continental shelf. In: Steele, J. H. (ed.) Spatial patterns in plankton communities. Plenum Press, New York, p. 181-220

Quéguiner, B. (1982). Variations qualitatives et quantitatives du phytoplancton dans un écosystème eutrophe fortement soumis aux effets des marées: la Rade de Brest. Thèse $3^{\text {ème }}$ cycle, Univ. de Bretagne Occidentale, Brest

Quéguiner, B., Tréguer, P. (1984). Studies on the phytoplankton in the Bay of Brest (Western Europe). Seasonal variations in composition, biomass and production in relation to hydrological and chemical features (1981-1982). Botanica mar. 27: 449-459

Quigley, M. A., Robbins, J. A. (1984). Silica regeneration processes in nearshore southern Lake Michigan. J. Great Lakes Res. 10: 383-392

Ragueneau, O., Tréguer, P. (1994). Determination of biogenic silica in coastal waters: applicability and limits of the alkaline digestion method. Mar. Chem. 45: 43-51

Redfield, A. C., Ketchum, B. H., Richards, F. A. (1963). The influence of organisms on the composition of sea water. In Hill, M. N. (ed.) The sea, Vol. II. John Wiley, New York, p. $26-77$

Rippey, B. (1983). A laboratory study of the silicon release process from a lake sediment (Lough Neagh, Northern Ireland). Arch. Hydrobiol. 96 (4): $417-433$

Schelske, C. L., Stoermer, E. F. (1971). Eutrophication, silica depletion and predicted changes in algal quality in Lake Michigan. Science 173: 423-424

Siever, R. (1962). Silica solubility at $0^{\circ}-200^{\circ} \mathrm{C}$ and the diagenesis of siliceous sediments. J. Geol. 70: 127-150

Smayda, T. J. (1970). The suspension and sinking of phytoplankton in the Sea. Oceanogr. mar. Biol. A. Rev. 8: $353-414$

Smayda, T J. (1990). Novel and nuisance phytoplankton blooms in the sea: evidence for a global epidemic. In: Graneli, E. (ed.) Toxic marine phytoplankton. Elsevier Science Publishing Co., New York, p. 29-40

This article was submitted to the editor
Smetacek, V. (1980a). Annual cycle of sedimentation in relation to plankton ecology in western Kiel Bight. Ophelia, Suppl. 1. $65-76$

Smetacek, V (1980b). Zooplankton standing stock, copepod faecal pellets and particulate detritus in Kiel Bight. Estuar. coast. Shelf Sci. 11: 477-490

Smetacek, V. S. (1985). Role of sinking in diatom life-history cycles: ecological, evolutionary and geological significance. Mar. Biol. 84: 239-251

Souchu, P. (1986). Contribution à l'étude du cycle de l'azote en écosystème macrotidal. Thèse $3^{\text {ème }}$ cycle, Univ. Bretagne Occidentale, Brest

Spencer, C. P. (1983). Marine biogeochemistry of silicon. In: Aston, S. R. (ed.) Silicon geochemistry and biogeochemistry. Academic Press, London, p. 101-141

Stober, W. (1967). Formation of silicic acid in aqueous suspensions of different silica modification. In: Stumm, W. (ed.) Equilibrium concepts in natural water systems. Amer. Chem. Series 67, Washington, DC, p. 161-182

Strickland, J. D. H., Parson, T. R. (1972). A practical handbook of seawater analysis. Bull. Fish. Res. Bd Can. 167

Tréguer, P., Le Corre, P. (1975). Manuel d'analyse des sels nutritifs dans l'eau de mer. Utilisation de i'Auto-Analyseur II: Technicon, $2^{\text {eme }}$ édition. Laboratoire d'Océanographie Chimique, Université de Bretagne Occidentale, Brest

Tréguer, P., Lindner, L., Van Bennekom, A. J., Leynaert, A., Panouse, M., Jacques, G. (1991). Production of biogenic silica in the Weddell-Scotia Seas measured with ${ }^{32} \mathrm{Si}$. Limnol. Oceanogr. 36: 1217-1227

Tréguer, P., Quéguiner, B. (1989). Seasonal variations in conservative and nonconservative mixing of nitrogen compounds in a west European macrotidal estuary. Oceanol. Acta 12: $371-380$

Utermöhl, M. (1931). Über das umgekehrte Mikroskop. Arch. Hydrobiol. Beih. Ergeb. Plankton 22: 643-645

Van Lier, J. A., De Bruyn, P. L., Overbeek, J. T. G. (1960). The solubility of quartz. J. Phys. Chem. 64: 1675-1682

Wangersky, P. J. (1977). The role of particulate matter in the productivity of surface waters. Helgoländer wiss. Meeresunters. 30: $546-564$

Yamada, S. S., D'Elia, C. F. (1984). Silicic acid regeneration. from estuarine sediment cores. Mar. Ecol. Prog. Ser. 18: $113-118$

Yentsch, C. S., Menzel, D. W. (1963). A method for the determination of phytoplankton chlorophyll and pheophytin by fluorescence. Deep Sea Res. 10: 221-231

Manuscript first received: July 23, 1993

Revised version accepted: January 10,1994 